\title{
PERSONNEL RECONVERSION - ELEMENT OF SOCIAL SECURITY FOR PROFESSIONAL SOLDIERS
}

Original article

Accepted: September 2020

Published: November 2020

Peer review:

Double blind

Keywords:

social security, military personnel, reconversion, restructuring

This work is licensed under the Creative Commons AttributionNonCommercial-NoDerivatives 4.0 License

\author{
Ryszard Chyrzyński ${ }^{1}$ \\ ORCID 0000-0003-2362-6826
}

Military University of Technology in Warsaw, gen. Sylwestra Kaliskiego 2, 01-476 Warszawa

\begin{abstract}
Purpose: The purpose of this article is to explain the process of military personnel reconversion, as well as to assess its impact on the improvement of the social security of soldiers discharged from professional military service as a result of the restructuring of the armed forces.

Method: The scientific methods used in the paper include: analysis and criticism of the literature on the subject, as well as logical analysis and construction. The research was carried out on the basis of data on the Polish Armed Forces.

Results: Analysis of the available sources allows for a thesis that reconversion of military personnel may have a significant impact on the improvement of the social security of military professionals and the condition of the armed forces, provided that the organizational and legal conditions are fully adapted to its needs.
\end{abstract}

Conclusions: Currently, reconversion of military personnel is carried out under optimal conditions and has the appropriate organizational potential and legal basis to secure the restructuring process of the Polish Armed Forces.

\footnotetext{
${ }^{1}$ Ryszard Chyrzyński, Ph.D. - a lecturer at the Institute of Security and Defence Systems at the Faculty of Security, Logistics and Management of the Military University of Technology in Warsaw. Research interests: issues related to the broadly understood security (including: economic and social security), public administration,
} 


\section{Introduction to the problem}

The political transformation of our country brought about a number of significant changes in the social, political and economic areas. These changes also took place in the army. It was necessary to carry out fundamental and, at the same time, rapid structural, organizational and personnel reforms in the Polish Armed Forces, as well as technical modernization of the army.

Although the purpose of the restructuring was generally modernization of the army, increasing its mobility and effectiveness, it also lead to a number of various social consequences. One of them was a drastic reduction of staff, both professional soldiers and military personnel, which was particularly difficult to implement, as not only the complex organizational, technical and economic conditions were involved, but also the moral, psychological and social aspects of this process.

Restructuring of the army involved not only the transformation of its structure, but also, to a large extent, workforce reduction at its various organizational levels. The main reason for these changes was the need to adapt the Polish armed forces to the structures, requirements and procedures in force in NATO.

From the very beginning this process was accompanied by reconversion measures, improved and adapted to the changing socio-economic conditions within the country and in the army. These measures were part of a series of legally regulated undertakings aimed at preparing soldiers discharged, as well as those to be discharged from professional military service (in particular those who have not completed the full term of service in order to be eligible for pension), to take up employment on the civilian labour market or to start their own business.

A review of legal regulations specifying the scope and tasks of government administration, including military administration ${ }^{2}$ and the competences of its bodies in the field of social security, allows for the conclusion that the role of these entities in this area has been very important, though at the same time very limited.

Considering the applicable legal regulations, the process of personnel reconversion in the Polish Armed Forces can be divided into two stages:

financing of the national defence system and strategic reserves, weapons and military equipment procurement systems.

${ }^{2}$ Understood as the functioning of military institutions in times of peace and covering all issues related to the armed forces that are outside of the scope of command and training, as well as all activities aimed at providing the army with essentials for its efficient functioning, in accordance with the tasks entrusted to it by the state. 
- the first stage involved the introduction of the process of personnel reconversion in the army, which gave the discharged military personnel an opportunity to prepare for work on the civilian labour market, it was implemented on the basis of the initiated restructuring of the Polish Armed Forces (until the end of 2009) ${ }^{3}$;

- the second stage involved the introduction of a fully professional army in Poland (since 2010).

\section{The concept of social security}

Security is the basic need of every human being and human communities, and is required for the creation and functioning of the values necessary for the existence of mankind. Measures undertaken to ensure it are the result of rational behaviour of individuals and communities.

Contemporary society is referred to as a "risk society" (Beck, 2002), which is faced with various types of threats, including wars, local and religious conflicts and pandemics, such as the coronavirus pandemic, which is decimating population around the world.

Security, apart from life, health and order, is one of the superior values on the scale of social and personal expectations of people. It is the cornerstone, on which people build a future for themselves and their families. It is also a basic good, which guarantees the proper development of the personal life of each individual, as well as stability and development of political, economic and social life.

In the era of great civilizational development and technological progress, the term "security" can be considered in two categories.

In the first one, security is regarded on a macro scale and involves global issues (concerning the whole world, individual continents, states or regions).

In the second category, security is regarded on a micro scale and involves personal matters (also those related to one's profession, be it a doctor, teacher, policeman, firefighter, official or military professional).

In the existing literature on the subject, there is a certain ambiguity and complexity related to the concept of "security", although, at the same time, attempts are made to define this term, taking into account all its aspects, as a result of which related terms appear, including: "national security”, "state security”, "public security”, "social security", "internal security", "external security" that are also used in various legal acts.

\footnotetext{
${ }^{3}$ Act of April 24, 2009 amending the act on military service of military professionals (Journal of Laws No. 79, item 669 , as amended).
} 
The concept of "social security" can be defined as the absence of threats to the functioning and interests of people, social and professional groups or people in general, enabling normal, unhindered development.

The main pillars of social security include two dimensions:

- economic - internal and external threats to the state economy, resulting from various economic dependencies;

- political - threats against the organizational stability of the state, its processes, institutions and laws.

Social security can undoubtedly be regarded as an interdisciplinary concept. In legal sciences, it is considered in the context of social welfare and social standards of an individual. It means, first and foremost, the protection that the state guarantees to its citizens by preventing economic and social poverty that may be caused by various factors and events (e.g. low income, illness, maternity, unemployment, disability, old age and death).

Social security is treated here as an obligation of the state (public administration) to guarantee certain social benefits for the entire society and for its individual social or professional groups (Chyrzyński, 2018, p. 437). The latter should primarily be understood as a protection of a given professional group (e.g. artists, doctors, teachers, professional soldiers) against negative impact or circumstances, which - regardless of the state political system - is an important area of the activity of government as an executive power in a democratic state.

In the case of military professionals, the protection referred to above involves counteracting problems that may arise in the area of social issues in the military environment (which includes both professional soldiers and their families), and is aimed at ensuring a proper level of existence of individuals, protection of their social standing and an adequate quality of their life by using internal and external measures that guarantee stability and development, the disruption of which may pose a threat to the functioning of the armed forces, and, consequently, to the security of the state.

The starting point for the concept of social security of military professionals defined in such a way are, in the first place, the interests of the armed forces, then the interests of the whole professional group (all military professionals), and finally the interests of an individual soldier (Chyrzyński, 2018, p. 441).

The social security of military professionals can be threatened mainly due to:

- military service within the country and abroad (in military missions);

- accidents on duty, during exercises and military operations; 
- changes in the structure and size of the armed forces resulting from the implemented restructuring and modernization processes.

Military professionals constitute a professional group, whose qualifications (general, military and specialist knowledge and skills) are primarily used to defend the country. They are permanently, systematically and purposefully involved in activities aimed at the protection of material goods produced by the society and other values, which also helps them to satisfy their own needs (especially economic and social) and provides them with a certain social standing.

This concept includes both the security of a single professional soldier and his family, as well as the security of the entire armed forces, in the broad sense of the word. It guarantees military professionals:

- protection of their health, life and property;

- acquired rights ${ }^{4}$;

- security in the performance of official duties during and after professional military service.

The contemporary world poses numerous threats, both those perceived subjectively and objectively. The continuous civilizational development and dynamic technological progress, as well as the search for optimal organizational and structural solutions, apart from its positive impact in the form of inventions and amenities that make life easier, has also generated numerous threats - both for individuals and groups of people.

State administration bodies (the government and local governments) perform the vast majority of the state's duties in terms of ensuring social security of the citizens. The military administration is also actively involved in the implementation of these tasks, and - under the applicable law - performs them mainly in relation to professional soldiers, military personnel and their families ${ }^{5}$.

In order to prevent this type of threats, permanent or temporary specialized bodies and institutions (at the central or local level) are established within the state (including in the military. Specific actions are also undertaken to limit their negative impact on the citizens, including various professional groups (doctors, teachers, policemen, firefighters, officials or professional soldiers). Personnel reconversion has been an example of such a measure to prevent unemployment, especially among the younger military professionals.

\footnotetext{
${ }^{4}$ Understood as providing individuals and professional groups with legal security and enabling them to rationally plan their future activities.
} 


\section{Personnel reconversion in the Polish Army}

The literature on the subject defines reconversion as the process of transferring the economy from the military-oriented to the civilian-oriented activities (Opaliński, 1989, p. 483). It is an extremely difficult and complex process, since it requires a fast and thorough restructuring of the economy from one entirely geared to the needs of war to one that focuses on meeting current and future social needs.

In the case of personnel reconversion, it is understood as returning to the level of education and skills acquired before entering a specific profession. The concept also be defined as a process aimed at adaptation of the surplus of workforce in a given professional group to new social or professional conditions.

Personnel reconversion in the military thus means a process aimed at management of the surplus of military resources, resulting from the change in the condition and structure of the armed forces due to restructuring and modernization. These measures can be regarded as a systemic process aimed at adaptation of the surplus of military workforce to new organizational, social or professional conditions.

Reconversion measures in the Polish Armed Forces have been implemented for a long time (for over 30 years) ${ }^{6}$ and they have a statutory legal basis ${ }^{7}$.

The first time that support was provided for soldiers leaving professional military service due to structural and organizational changes in the Polish Armed Forces was in December 1992, when the Ministry of National Defence informed the Ministry of Labour and Social Policy about a reconversion training in the army for over 3,000 professional soldiers discharged due to the lack of full-time positions in the new organizational structures of the army, as well as another 10 thousand soldiers who were waiting for such a training.

The thematic content of the training courses organized at various organizational levels in the army for discharged professional soldiers resulted mainly from the needs of the labour market at that time and covered:

- self-employment,

- personal and property protection,

\footnotetext{
5 These tasks do not apply to military personnel who, pursuant to the Act of December 14, 1994 on employment and counteracting unemployment, remain the responsibility of the local government, including labour office.

${ }^{6}$ On May 7, 1990, the position of the Representative of the Minister of National Defence for Human Resources of Units (staffs) Subject to Restructuring - Deputy Head of Human Resources - was introduced.

${ }^{7}$ Art. 88a of the Act of 30 June 1970 on professional military service (Journal of Laws of 1997, No. 10, item 55, as amended).
} 
- technical courses (e.g. for the profession of a driver, mechanic, operator of construction heavy equipment).

Foreign language training courses (especially English) were also conducted.

In principle, reconversion measures, undertaken for the needs of military personnel and adapted to the conditions of the army at that time, were mainly aimed at employment support and preparation of the discharged and former professional soldiers to take up employment in a new workplace in order to keep - to the possible extent - their social and material status. It was particularly beneficial for discharged professional soldiers who had not completed the full term of service in order to be eligible for the full armed forces pension and had no other professional skills useful on the civilian labour market.

At the same time, due to the specific nature of the profession in question, an important goal and, at the same time, result of these measures, was, as it were, a mental reconversion of the soldiers in the course of their preparation to enter the civilian labour market. This undoubtedly helped to reduce the stress and prevent possible conflicts during the process of dismissal from professional military service.

In terms of counteracting unemployment, the model of services to mitigate the consequences of group redundancies developed by the National Employment Office was in force at that time, as a nationwide system of reconversion implemented by labour offices ${ }^{8}$.

The program included:

- organization of orientation meetings with the management and employees of the workplaces where group redundancies were planned;

- counselling duty hours;

- granting loans for starting a business.

Initially, reconversion measures in the army were implemented on the basis of a number of (not always coherent) legal acts, which prevented their unambiguous interpretation and practical application. The provisions regulating reconversion measures were included in:

- Art. 133a of the Act of November 21, 1967 on the universal obligation to defend the Republic of Poland ${ }^{9}$;

- Art. 88 and 88a of the Act of June 30, 1970 on the professional military service ${ }^{10}$;

- Art. 21 sec. 3 of the Act of 18 December 1998 on the civil service ${ }^{11}$;

\footnotetext{
${ }^{8}$ Prepared on the basis of the Act of October 16, 1991 on employment and unemployment (Journal of Laws No. 106 , item 457 , as amended).

${ }^{9}$ Journal of Laws of 2015, item 827, as amended.

${ }^{10}$ Journal of Laws of 1997, No. 10, item 55, as amended.

${ }^{11}$ Journal of Laws of 1999 No. 49, item 483, as amended.
} 
- Art. 4 sec. 2 point $2 \mathrm{f}$ of the Act of May 25, 2001 on the reconstruction, technical modernization and financing of the Polish Armed Forces in the years 2001-2006 ${ }^{12}$;

- Art. 119 and 120 of the Act of September 11, 2003 on the professional military service $^{13}$;

- Regulation of the Prime Minister of September 26, 1997 on the determination of job positions related to national defence ${ }^{14}$;

- Regulation of the Minister of National Defence of 11 June 1997 on detailed rules and procedures for vocational training or retraining, career counselling, apprenticeship and recruitment services, implemented by specialized military entities, as well as detailed rules and conditions for receiving assistance in the mentioned areas by soldiers discharged from professional military service ${ }^{15}$;

- Regulation of the Minister of Labour and Social Policy of October 14, 1997 on the detailed rules and procedures for placement of soldiers discharged from professional military service in positions related to national defence ${ }^{16}$.

With regard to former professional soldiers, the following legal regulations also applied:

- Art. 14 - 17 of the Act of December 14, 1994 on employment and counteracting unemployment ${ }^{17}$;

- the Agreement of March 25, 1999 between the Ministry of National Defence and the Labour Office on cooperation in mitigating the consequences of unemployment among former professional soldiers (not published);

- the Agreement of October 17, 2002 between the Minister of National Defence and the Commander-in-Chief of the Border Guard on cooperation in terms of admission of former professional soldiers to the Border Guard service ${ }^{18}$;

- the Agreement of April 29, 2003 between the Minister of National Defence and the Police Commander in Chief on cooperation in terms of admission of former professional soldiers to the Police service ${ }^{19}$.

All undertakings related to the reconversion measures in the army, along with specific goals and actions, were included in the form of a plan in:

\footnotetext{
12 Journal of Laws No. 76, item 804, as amended.

${ }^{13}$ Journal of Laws of 2014, item 1414, as amended.

${ }^{14}$ Journal of Laws No. 124, item 787, as amended.

15 Journal of Laws of 1997, No. 63, item 398, as amended.

${ }^{16}$ Journal of Laws of 1997, No. 134, item 888, as amended.

${ }^{17}$ Journal of Laws of 2001, No. 6, item 56, as amended.

${ }^{18}$ Not published.

${ }^{19}$ Not published.
} 
- "The program of reconstruction and technical modernization of the Polish Armed Forces in 2001-2006";

- "Reconversion plan for soldiers discharged from professional military service in 2003-2008" (the Minister of National Defence was obliged to submit to the Council of Ministers every 6 months a "Report on the implementation of the 'Program for the reconstruction and modernization of the Polish Armed Forces' in terms of the effectiveness of personnel reconversion ${ }^{20}$ ).

In order to implement these tasks - quite specific for the army - a special organizational structure was established, which was entrusted with providing reconversion support for soldiers discharged or to be discharged from professional military service.

These tasks were carried out by:

at the central level:

- the Department of Human Resources and Higher Education, and then the Department of Human Resources (until 2000);

- the Department of Social Affairs and Reconversion (since 2001), then the Department of Social Affairs (since 2006);

- $\quad$ at the local level:

- $\quad$ the Military Employment Support Centre in Warsaw;

- 4 employment support centres in Bydgoszcz, Kraków, Olsztyn and Wrocław);

- full-time representatives of commanders (chiefs) for reconversion in individual branches of armed forces, military districts and in 16 provincial military headquarters;

- commissioned specialists for reconversion - in 10 garrisons of the Land Forces, three garrisons of the Air Force and Air Defence and the Air Force Academy.

Among important legal regulations, which organized and defined the framework of reconversion measures in the army, was, in particular, the Act on professional military service $^{21}$, amended in 1997 . The provisions introduced by this Act allowed to take advantage of reconversion support for soldiers who:

o were not eligible for the full armed forces pension (75\% of the calculation basis);

o were discharged from the military service due to:

- being declared by the military medical board as unfit to continue professional military service;

\footnotetext{
${ }^{20}$ Minutes of the meeting of the Council of Ministers of October 22, 2002.
} 
- termination of the period of service specified in the contract, if the soldier had completed at least two contracts;

- voluntary discharge requested by the soldier or a competent military authority.

At the same time, in terms of reconversion support, the Act excluded professional soldiers who:

- $\quad$ had requested discharge during the period of the mandatory military service;

- $\quad$ were eligible for the full armed forces pension ${ }^{22}$;

- $\quad$ were discharged from professional military service before February 24, 1996;

- $\quad$ were on contract service after the completion of the first contract.

Reconversion support was, therefore, granted to soldiers discharged from professional military service, as well as to those whose service relationship was terminated by a military authority. This group of soldiers were able to take advantage of the support from the moment they received notice (i.e. 9 months before the discharge from the military service).

Under the legal circumstances at that time, a number of measures were implemented in the Polish Armed Forces as part of reconversion support, including:

- Reconversion seminars - 3-day information and counselling meetings aimed at: familiarization of the soldiers with the possibilities offered by the program of reconversion support, providing information about employment opportunities on the civilian labour market, as well as determination of their professional predispositions in order to facilitate the optimal selection of their further professional career.

- Career counselling - individual and group career counselling sessions, information, training and integration activities with elements of psychotherapy, as well as personality testing. The aim of these activities was to optimize the soldiers' decisions regarding their choice of a new profession, place of employment and the field of retraining. They prepared soldiers for a targeted, and thus more effective, job search after being discharged from professional military service.

- Vocational training or retraining - conducted individually or in groups, financing or reimbursement of training costs to supplement existing qualifications or acquire new ones, useful for continuing professional activity on the civilian labour market.

- Apprenticeship - constituting an integral part of professional retraining, preceding

${ }^{21}$ The Act of June 30, 1970.

${ }^{22}$ The full armed forces pension should be understood as a pension in the amount of $75 \%$ of the calculation basis, taking into account all elements that affect its amount. 
the employment of former professional soldiers in a specific position in a new workplace.

- Job placement services - consisting in the provision by specialized military entities of support to soldiers discharged from professional military service, by presenting them with job offers or providing them with job placement services.

- Job fairs - part of the reconversion support program indirectly assisting in the employment of former professional soldiers, and also promoting their personal and professional skills on the civilian labour market.

Other forms of reconversion support that were gradually introduced in the army include:

- Support of self-employment - mechanisms and instruments enabling former professional soldiers to take advantage of redundant military property and to obtain aid funds from non-budgetary sources.

- Business incubators - created as part of a pilot program implemented jointly with provincial labour offices, in facilities of dissolved military units. The main purpose of the business incubators was to help newly established companies, created by former professional soldiers, to reach maturity and to function independently. Their purpose was also to provide small businesses with a space adequate for their business needs, and offer office and support services, such as economic, financial, legal, organizational and technical consultancy, as well as enabling access to financing, marketing and management sources.

Table 1 presents summarized data on the number of professional soldiers who took advantage of various forms of reconversion support in the initial period of the personnel reconversion process in the army.

Table 1. Summarized data on the number of professional soldiers who took advantage of reconversion support in $1996-1999$

\begin{tabular}{|l|c|c|c|c|}
\hline \multicolumn{1}{|c|}{ Specification } & \multicolumn{3}{c|}{ Years } \\
\cline { 2 - 5 } & 1996 & 1997 & 1998 & 1999 \\
\hline $\begin{array}{l}\text { Number of soldiers discharged from } \\
\text { professional military service }\end{array}$ & 6627 & 6493 & 8163 & 2414 \\
\hline $\begin{array}{l}\text { Number of soldiers eligible for reconversion } \\
\text { support }\end{array}$ & 4970 & 4870 & 6122 & 1810 \\
\hline
\end{tabular}




\begin{tabular}{|c|c|c|c|c|}
\hline \multicolumn{5}{|c|}{ Various forms of reconversion support provided } \\
\hline $\begin{array}{l}\text { Number of beneficiaries of various forms of } \\
\text { support, including: }\end{array}$ & 2744 & 2724 & 3251 & 3130 \\
\hline - retraining & 406 & 317 & 543 & 1128 \\
\hline - vocational counselling & 1247 & 1263 & 1451 & 1245 \\
\hline - reconversion seminars & 194 & 318 & 1132 & 413 \\
\hline - job placement services & 1091 & 1144 & 1257 & 757 \\
\hline \multicolumn{5}{|c|}{ Employment as a result of the granted reconversion support } \\
\hline Number of soldiers employed & 160 & 332 & 376 & 569 \\
\hline \multicolumn{5}{|c|}{ Retraining costs } \\
\hline $\begin{array}{l}\text { Total cost in the budget of the Ministry of } \\
\text { National Defence (in PLN thousand) }\end{array}$ & 127 & 261 & 567 & 1447 \\
\hline $\begin{array}{l}\text { Average cost per } 1 \text { participant of the } \\
\text { reconversion support program (in PLN) }\end{array}$ & 313 & 820 & 1044 & 1286 \\
\hline
\end{tabular}

Source: Based on the document "Rekonwersja kadr w Sitach Zbrojnych RP" ("Personnel reconversion in the Polish Armed Forces"), prepared by the Department of Social Affairs and Reconversion at the meeting of the Ministry of National Defence, Warsaw 2002

It is worth to mention at this point the scale of the problems that emerged in the army in the initial period of the development and introduction of the reconversion process.

For instance, as a result of the restructuring of the Polish Armed Forces in the years 1996-2001 over 28.6 thousand military professionals left the army, out of which 21.8 thousand $(76.2 \%)$ took advantage of various forms of reconversion support available at that time. Almost 18 thousand of discharged soldiers were not eligible for the full armed forces pension $^{23}$. The vast majority were under the age of 45 , including soldiers in their 30 s without any entitlements (not eligible for a partial retirement pension nor having any capital accumulated in the Social Insurance Institution, as they had not been paying social security contributions) $)^{24}$.

Due to the reconversion support, approx. 2,700 soldiers discharged from professional military service $(9.4 \%)$ found employment on the civilian labour market ${ }^{25}$. It should be noted

\footnotetext{
${ }^{23}$ Right to $75 \%$ of the retirement pension calculation basis.

${ }^{24}$ Data of the Department of Social Affairs and Reconversion from 2003.

25 This number does not include discharged soldiers who started their own business, found a new job themselves or with the help of job placement agencies.
} 
that at that time there was a very large scale of unemployment in Poland, which made it even more difficult for the soldiers to find any job.

It also had an impact on the evaluation of the reconversion measures undertaken at that time, which - from the point of view of the organization itself, but also due to decreasing annual financial expenditure allocated to its functioning in the budget of the Ministry of National Defence - was not too high. Undoubtedly, the limited scope and effectiveness of various measures was influenced by many factors.

One of such factors was underfinancing:

- in 2000 - the allocated funds in the budget of the Ministry of National Defence amounted to PLN 1,595.7 thousand;

- when the 6-year program of reconstruction and modernization of the Polish armed forces was first launched, which led to large-scale redundancies, only PLN 1,159.1 thousand was allocated for reconversion support.

It should be stressed that national defence is not a good that exists in nature in excess in relation to our current needs and it is not enough just to take care of it (such as in the case of the natural environment) in order to protect it. National defence is a good that must be financed by the society in a conscious manner, taking into account its significance, potential, but also cost-effectiveness (Chyrzyński, 2016, p. 171).

Another important factor in evaluation of the measures undertaken was the limited organizational structures. By February 2000, there were only 4 full-time positions in within the commands of the individual branches of Armed Forces and military districts, and 33 fulltime positions in the remaining organizational levels of the Polish Armed Forces. In addition, some civilian staff employed in provincial military headquarters and in army recruiting commands were also engaged in the activities on a part-time basis.

On the other hand, some positive results were achieved due to informal cooperation between circles of former professional soldiers and those still in service. Although there were no structures strictly dealing with reconversion within the organizational units of former professional soldiers, many ideas originated from such organizations (for example, during meetings of former professional soldiers' unions).

It should be mentioned that some of the soldiers were completely unaware of the support and reconversion programs available in the army at that time.

On the basis of a research carried out at that time ${ }^{26}$, it can be said that the most

\footnotetext{
${ }^{26}$ Research conducted by the Department of Social Affairs and Reconversion in 2003.
} 
important criteria for granting the reconversion support in the army included:

$\circ$ the situation on the labour market in the place of residence of the discharged soldier $(80,7 \%)$

- years of service $(80 \%)$;

- age $(74 \%)$

- current financial situation $(68,9 \%)$;

- number of dependants $(67,8 \%)$;

- qualifications enabling finding employment on the civilian labour market $(65,1 \%)$;

- type of garrison, where the former soldier served $(62,8 \%)$;

- place of residence $(59,4 \%)^{27}$.

In turn, the research subjects had the following expectations in terms of reconversion support in the event of their discharge from professional military service:

- assistance in finding a job on the civilian labour market by presenting specific job offers $(24,1 \%)$;

- the possibility of further professional development, improving qualifications through participation in training and courses $(23,9 \%)$;

- $\quad$ an adequately high severance pay $(9,8 \%)$;

- ensuring an adequate standard of living for soldiers and their families (7,8\%);

- application of solutions already tested in the sectors of the national economy subject to restructuring, e.g. in the mining sector $(5,5 \%)$;

- high early retirement pensions or cash equivalent for the remaining years required to become eligible to receive full retirement pension $(4,4 \%)$;

- other respondents $(24.5 \%)$ had no opinion regarding this subject.

In general, it can be said that the opinions, beliefs and assessments of the professional soldiers subject to the research did not fully reflect the actual state of affairs, as they carried a certain emotional load (e.g. fear of being discharged from the army) and were highly subjective (which should come as no surprise).

At the same time, it should be noted that the research did not precisely define who the respondents were, using the term "personnel facing discharge from military service", which could suggest the lack of certainty in terms of obtaining objective knowledge about the respondents' attitude to reconversion measures. This was mainly due to the fact that the nature

\footnotetext{
${ }^{27}$ Information and data of the Department of Social Affairs and Reconversion of the Ministry of National Defence from 2003.
} 
of the research often combined the respondents' views on issues related to the system of social security (or the lack thereof) with the system of personnel reconversion in the Polish Armed Forces.

In this way, the perception of the situation related to the research problem could be distorted, as negative opinions were transferred from one set of problems to another one and vice versa. What was also clearly visible in the respondents' opinions were the so-called existential fears ${ }^{28}$. It is hardly surprising, since the point of reconversion measures is to help overcome the fears related to entering the civilian labour market - not to guarantee work for all those leaving the professional military service.

At this point it should be clearly emphasized that the personnel reconversion system is only effective if the labour market - especially the local one - offers adequate employment opportunities. On the other hand, in the case of a depressed labour market, actions limited to reconversion measures do not ensure success in counteracting unemployment. For this reason, the reconversion measures also required significant investment outlays, which was difficult, especially in the years 1996-2003, due to the lack of sources of financing (low level of gross national income), as well as the inability to fully satisfy the current needs of the population (the increase in consumption was much larger than under normal conditions of competitiveness in relation to the investments).

Significant changes in the functioning of the Polish Armed Forces, and also in the reconversion measures undertaken, took place as a result of the adoption of the Act on the reconstruction, technical modernization and financing of the Polish Armed Forces in 2001$2006^{29}$. With regard to reconversion measures, this act made it possible to:

- shorten, at the request of the soldier, the 9-month notice period given by the military authority to no more than one month - for this period the discharged soldier was entitled to receive a one-time compensation in the amount of a one-month basic salary with fixed allowances due for the last official position held, for each month the notice period was reduced by;

- use the property that had belonged to organizational units subordinated to or supervised by the Ministry of National Defence and was transferred to the Military Property Agency - priority was given to soldiers discharged from professional military service due to dissolution of military units (institutions);

\footnotetext{
${ }^{28}$ Understood as an unpleasant emotional state related to the anticipation of an external or internal danger, which is manifested in anxiety, tension, embarrassment or the sense of danger.

${ }^{29}$ Act of May 25, 2001 (Journal of Laws 2001, No. 76, item 804).
} 
- transfer redundant assets or property of the Ministry National Defence in order to make them available for former professional soldiers for conducting their business activity.

\section{Personnel reconversion in the Polish Army at present}

2010 was in many respects a breakthrough moment for personnel reconversion in the army. In addition to the implementation of new legal regulations determining the principles of professional military service ${ }^{30}$, based on a fully professional army, the scope and principles of new personnel reconversion programs adapted to that army were also described. A successful attempt was also made to provide reconversion support to the discharged military staff.

2010 was the first year, when the results of previously undertaken actions could be observed, including, in particular, organizational and structural changes, after the expansion and subordination of local reconversion units to the Military Employment Support Centre. It turned out that these undertakings, both in structural and legal terms, were appropriate and fully adapted to the new army.

According to the new legal regulations, a former professional soldier ${ }^{31}$, who:

- was discharged from professional military service after being declared by the military medical board as unfit to continue professional military service as a result of an accident during active military service, or

- has contracted a disease as a result of nature or conditions of military service, or

- has performed professional military service for at least 4 years,

within the period of 2 years from the date of being discharged from the military service, acquires the right to receive reconversion support in the field of career counselling, retraining and job placement services.

On the other hand, a former professional soldier who meets the above-mentioned conditions and has also served outside the country ${ }^{32}$, acquires the right to such a support indefinitely.

${ }^{30}$ Amended act on professional military service.

${ }^{31}$ The above-mentioned regulations do not apply to soldiers discharged due to:

- renunciation or losing Polish citizenship,

- a legally binding decision imposing a disciplinary penalty of dismissal from professional military service,

- a final and binding decision on penal measures involving deprivation of public rights, expulsion from professional military service or prohibition to practice the profession of a professional soldier,

- being sentenced by a legally-binding decision of the court to imprisonment (military detention) without a conditional suspension of its execution,

- a valid punishment by the competent professional self-governing body with the suspension or deprivation of the right to practice the profession - Art. 111 points 1 and 12-15 of the Act of September 11, 2003.

${ }^{32}$ Related to the implementation of the objectives referred to in Art. 2 point 1 of the Act of December 17, 1998 on the rules of use or stay of the Polish Armed Forces outside the country (Journal of Laws No. 23, item 119, as amended). 
In addition, a professional soldier, with the consent of the commander of the military unit, may also take advantage of assistance in the following fields:

- professional counselling - provided that the soldier has performed professional military service for at least 3 years;

- professional retraining and job placement services (2 years before discharge from professional military service) - provided that the soldier has performed professional military service for at least 4 years;

- apprenticeship (6 months before discharge from professional military service) provided that the soldier has performed professional military service for at least 9 years.

At the same time, the right to such an indefinite reconversion support is acquired by the spouse and dependent children of the professional soldier who:

- has died or went missing in action during the performance of official duties,

- has died within the period of 3 years after being discharged from professional military service as a result of an accident or disease related to his or her official duties.

As part of reconversion support for eligible persons, the following measures are currently being implemented:

- career counselling - it includes individual counselling, as well as group information, training and integration meetings and psychological testing. The aim of these measures is to facilitate the choice of a profession, workplace or field of retraining, teach how to prepare necessary application documents, as well as help to acquire selfpresentation skills for job interviews;

- vocational retraining - involves changing one's qualifications to new ones in order to adapt to the needs of a new profession, or increasing the level of existing qualifications within the same profession. Persons eligible for vocational retraining may participate in courses, training, studies and other forms of education. The process of retraining is personalized and preceded by counselling (the participant indicates the place, time, type of training and the institution that provides it);

- apprenticeship - allows to use and verify the skills acquired in the course of professional service and education, under conditions similar to work to be performed in the future. Eligible professional soldiers may take advantage of this form of reconversion support if it constitutes an integral part of a retraining program that increases the chances of finding employment;

- job placement services - assistance in finding suitable employment, mainly in the form 
of presenting job offers to soldiers and introducing suitable employees to employers. The job offers mentioned include both those available on the civilian labour market, as well as those related to national defence and crisis management units, prepared for operations in times of natural disasters;

- job fairs - organized for potential employees interested in taking up employment on the civilian labour market. They constitute an important element of the reconversion support system, and are an extension of job placement services. They also serve to promote the qualifications of professional soldiers on the civilian labour market.

Table 2 presents a comparison of the legal solutions related to the personnel reconversion system in the army in force at the time of its creation (until 2009) and at present (since 2010).

Table 2. Comparison of personnel reconversion systems in the Polish Armed Forces

\begin{tabular}{|c|c|}
\hline $\begin{array}{l}\text { PERSONNEL RECONVERSION SYSTEM } \\
\text { IN FORCE UNTIL } 2009\end{array}$ & $\begin{array}{l}\text { PERSONNEL RECONVERSION SYSTEM } \\
\text { IN FORCE SINCE } 2010\end{array}$ \\
\hline \multicolumn{2}{|c|}{$\begin{array}{ll}\text { ELIGIBILITY } \\
\end{array}$} \\
\hline $\begin{array}{l}\text { Professional soldiers discharged from } \\
\text { military service for reasons attributable to the } \\
\text { armed forces }\end{array}$ & $\begin{array}{l}\text { All soldiers discharged from professional } \\
\text { military service with exceptions }\end{array}$ \\
\hline $\begin{array}{c}\text { Soldiers discharged from active military } \\
\text { service due to permanent or temporary } \\
\text { inability to continue military service } \\
\text { as a result of an accident or disease } \\
\text { contracted in connection with active military } \\
\text { service }\end{array}$ & \\
\hline \multicolumn{2}{|c|}{$\begin{array}{c}\text { A spouse and dependent children of a professional soldier or a soldier discharged from active } \\
\text { military service who went missing or died during the performance of official duties, or died } \\
\text { within } 3 \text { years after being discharged from military service following an accident or illness } \\
\text { related to the performance of official duties }\end{array}$} \\
\hline \multicolumn{2}{|c|}{ TIME FRAME } \\
\hline & $\begin{array}{l}\text { - after } 3 \text { years of service - career } \\
\text { counselling } \\
\text { - } 2 \text { years before discharge (min. } 4 \text { years } \\
\text { of service) - vocational retraining, job } \\
\text { placement services, } \\
\text { - } 6 \text { months before discharge - } \\
\text { apprenticeship }\end{array}$ \\
\hline 2 years after discharge from military service & 2 years after discharge from military service \\
\hline \multicolumn{2}{|c|}{ Indefinitely* } \\
\hline
\end{tabular}


soldiers.

Source: Based on information obtained from the Department of Social Affairs of the Ministry of National Defence

The reconversion measures in the Polish Armed Forces are currently carried out by the following organizational structures:

at the central level:

- the Department of Social Affairs;

at the local level:

- the Military Employment Support Centre in Warsaw,

- 7 employment support centres in Bydgoszcz, Gdynia, Kraków, Lublin, Olsztyn, Szczecin and Wrocław,

- 8 military pension offices (in Bydgoszcz, Gdańsk, Kraków, Lublin, Olsztyn, Szczecin, Warsaw and Wrocław),

- 16 provincial military headquarters.

The data presented in this chapter on the functioning of the reconversion system in the Polish Armed Forces allows for the following conclusions and generalizations:

- the scope of personnel reconversion support varies and depends mainly on the pace of restructuring carried out in the armed forces and the budgetary availability of the Ministry of National Defence;

- the effectiveness of the reconversion measures depends, to a large extent, not so much on the proper organization and scope of these measures in the armed forces, but mainly on the possibilities offered by the civilian labour market (level of unemployment);

- any systemic changes in terms of reconversion support require the appropriate legal basis and additional funds from the budget;

- negative evaluation of reconversion support by professional soldiers resulted mainly from their fears related to their professional career and future;

- greater awareness among professional soldiers of the possibilities offered by the personnel reconversion support system is likely to significantly reduce negative attitudes in this regard in the armed forces;

- personnel reconversion has been necessary for the proper management of human resources in the armed forces, and it is likely to be implemented even to a larger extent along with the pace of reforms carried out in the armed forces.

In order to illustrate the scale and forms of solutions adopted in the Polish Armed 
Forces in terms of personnel reconversion, for comparison, the next chapters describes the solutions previously and currently used in selected NATO countries.

\section{Personnel reconversion systems in selected NATO countries}

The restructuring process of the armed forces - resulting from the political changes taking place in Europe and the adoption of a new strategic doctrine - was initiated practically at the same time in most of the armies of the North Atlantic Treaty Organization (NATO) member states. Naturally, it was implemented at different pace, facing various problems.

In most NATO armies, the professional military service is considered in terms of:

- HR policies;

- personnel planning in the armed forces, which begins at the moment of starting the career of a professional soldier, military service for a specific period and career completion;

- reconversion to active professional life in civilian environment.

It is the final stage in the career of every professional soldier that is treated with the utmost seriousness in the armies of NATO member states, since, as the saying goes "the end crowns the work", which is why states, out of concern for the prestige of the profession of the soldier and recruitment of the best personnel to the army, take upon themselves special obligations towards their soldiers (Wierzyński, 2001, p. 160). Countries of Western Europe, such France, Denmark or the Netherlands, have the most developed reconversion systems and structures, which are adapted to the changing needs in terms of the size of the armed forces.

The personnel reconversion system also helps to maintain the appropriate perception of the army and soldiers in the society, as social support for the army also depends on how efficient the reconversion support is in terms of facilitating the start of a second career for former soldiers. As it is stressed, for instance, in France, the quality of military personnel is determined not only by the criteria and procedure of military recruitment, but also by the treatment of those who leave military service. The discharged military professionals cannot be left without support, they have the right to count on the help of the institution that they served for. An appropriate treatment of discharged soldiers can also be regarded as an element of recruitment strategy to attract the best candidates for the army.

Reconversion of personnel (especially military personnel) in the main NATO countries consists in:

- creating a system of material (especially financial) incentives for voluntary redundancy from the army for soldiers who are ready in terms of age to start a civilian professional 
career, who have completed a specified number of years of service, hold a specific military rank and position, and whose departure from military service would be beneficial for the army and for their own interests;

- taking advantage of legal regulations - making it easier for discharged soldiers to find employment on preferential terms in the army as civilian staff, as well as in sectors of the economy or positions related to state defence;

- the functioning of full-time units at all levels of command - responsible for providing support to discharged soldiers and offering them assistance in terms of retraining, career counselling, job placement services and other individual forms of assistance under the broadly understood scheme of professional adaptation to civilian conditions;

- using existing enterprises on the civilian labour market to support the reconversion programs, especially in the field of retraining and job placement.

The Armed Forces of France boast the most developed military personnel reconversion system, which has a separate statutory regulation. The system can be used by all professional and contract soldiers (with at least 4 years of service completed). It is estimated that approx. 10,000 people benefit from the reconversion support there on an annual basis.

When the restructuring of the armed forces began, a specialized organizational unit was established in the French Ministry of Defence ${ }^{33}$, which was responsible for the preparation of legal, technical, organizational and financial guidelines related to the reconversion policy. Specialized organizational units were also established at the level of individual branches of armed forces and the national gendarmerie ${ }^{34}$. In addition, due to the specific nature of the health service and ordnance services, separate organizational units responsible for the reconversion of personnel in these sectors were also established.

At the same time, 8 general military reconversion centres were established in the armed forces, which conducted 6-month courses for privates and professional non-commissioned officers who were leaving the army and were looking for employment on the civilian labour market. While they were participating in these courses, the soldiers were receiving full salaries or special daily allowances.

A separate Association for Civil Reconversion of Officers was functioning as well, which provided help also to non-commissioned officers. There were also other associations and unions of soldiers and their families operating in the French armed forces, which offered

\footnotetext{
${ }^{33}$ Directorate of Military Service and Civilian Personnel.
} 
various types of social assistance for the military personnel and their families, but usually did not participate in the personnel reconversion programs.

Typical reconversion support in France was implemented in three stages:

- I stage - involved informing about possible forms of support (according to the needs and preferences of the beneficiary) and the principles of reconversion. 2- to 4-day free seminars were also organized, mainly by HR department heads of individual branches of armed forces and the Association for Civil Reconversion of Officers.

- II stage - involved reconversion support in the form of training (taking place several months before being discharged from the army), conducted at various retraining centres, companies or other institutions. The purpose of these trainings was to facilitate the process of finding a job and adaptation to a new workplace during probation period.

- III stage - involved various types of support and aid offered to soldiers(up to 15 days for those starting their own business and up to 6 months for those taking up employment in civilian enterprises). Subsequently, follow-up meetings were organized between the reconversion advisors and the former soldiers, during which the effectiveness of the reconversion support granted was assessed.

It is generally believed that the optimal time to start the reconversion process, necessary both for the administration and reconversion organizations, as well as for the soldier themselves, is two years before being leaving the military service. What is important is to maintain an appropriate motivation for retraining and choose the appropriate future carrer - in most cases different from the one previously pursued.

The comparison of the Polish system of personnel reconversion with the French one shows some similarities. The main point of difference is an insufficient amount of personnel and resources used for its implementation in the Polish army.

It is worth adding that the countries that joined NATO after Poland (Estonia, Lithuania, Bulgaria), when creating their own systems of personnel reconversion, often modelled them on the Polish one.

\section{Conclusions}

The political transformation in Poland brought about a number of significant changes in

\footnotetext{
34 At the level of individual branches of the armed forces, these were: Bureau of Vocational Training and Reconversion of Military Personnel of the Land Forces, Vocational Training and Reconversion of Military
} 
the social, political and economic areas. These changes also took place in the army. It was necessary to carry out fundamental and, at the same time, rapid structural, organizational and personnel reforms in the Polish Armed Forces, as well as technical modernization of the army.

Although the purpose of the restructuring of the Polish Armed Forces was in general modernization of the army, increasing its mobility and effectiveness, it also lead to a number of various social consequences. One of them was a drastic reduction of staff (both military and civilian personnel), which was particularly difficult to implement, as not only the complex organizational, technical and economic conditions were involved, but also the moral, psychological and social aspects of this process.

Restructuring of the Polish armed forces, implemented since early 1990s, involved not only the transformation of its structure, but also, to a large extent, workforce reduction at its various organizational levels. The main reason for these changes was the need to adapt the Polish army to the structures, requirements and procedures in force in NATO.

Personnel reconversion includes all activities undertaken by specialized military bodies for the purposes of:

- optimization of the decision-making process of professional soldiers discharged or to be discharged from professional military service, in terms of preparation for taking up employment outside the military;

- supplementing or acquiring new qualifications by discharged soldiers;

- finding employment for the discharged soldiers appropriate to their education, professional potential and aspirations.

The personnel reconversion system serves not only as a back to work scheme for military professionals, but helps to maintain the appropriate perception of the army and soldiers in the society as well, as social support for the army also depends on how efficient the reconversion support is in terms of facilitating the start of a second career for former soldiers in the civilian environment.

Social respect for soldiers, also after their discharge from military service, creates a positive image of the army, generates respect, and at the same time has a positive effect on the morale of soldiers, strengthening the integration and solidarity of the army as a professional group.

Undoubtedly, the process of personnel reconversion in the Polish army has significantly

Personnel of the Marine Forces, Reconversion Bureau of the National Gendarmerie. 
contributed to the mitigation of negative consequences of unemployment on the civilian labour market among soldiers discharged from professional military service.

One of the most optimal reconversion solutions would be to employ discharged professional soldiers in civilian positions within bodies or institutions of state administration (at the national and local level), where tasks related to national defence are carried out. However, despite numerous initiatives and efforts, the procedure of recruiting formal professional soldiers in these has not been fully implemented.

Within the armed forces, the personnel reconversion process should become one of the key tasks, the importance of which should increase with the progressing reduction of workforce. It should become an important element of the military human resources policy, facilitating the reform of the organizational structure of the armed forces, and a factor enabling a productive use of work capabilities of former soldiers in positions within the national economy and state administration sectors. 


\section{References}

Beck, U. (2004) Społeczeństwo ryzyka. W drodze do innej nowoczesności. Warszawa: Wydawnictwo Scholar.

Chyrzyński, R. (2016) 'Budżet obronny, budżet wojskowy a potrzeby bezpieczeństwa państwa', in Z. Trejnis \& M. Marciniak [eds.], Obronność państwa, Strategie oraz systemy bezpieczeństwa i obronności. Warszawa: Wydawnictwo Adam Marszałek.

Chyrzyński, R. (2018) 'Wyzwania i zagrożenia dla bezpieczeństwa socjalnego żołnierzy zawodowych' in. Z. Trejnis (ed.) Wyzwania i zagrożenia bezpieczeństwa i obronności RP w XXI wieku $w$ wymiarze polityczno-militarnym $i$ ekonomicznym. Warszawa: Oficyna Wydawnicza ASPRA-JR.

Opaliński, K. (1989) Słownik wyrazów obcych i zwrotów obcojęzycznych. Warszawa, „Wiedza Powszechna”.

Wierzyński, J. (2001) 'Rekonwersja kadr w wybranych państwach NATO', Myśl Wojskowa, 3.

\section{Legal acts}

Ustawa z dnia 30 czerwca 1970 r. o stużbie wojskowej żotnierzy zawodowych (jednolity tekst Dz. U. z 1997 r. Nr 10, poz. 55, z późn. zm.).

Ustawa z dnia 16 października 1991 r. o zatrudnieniu i bezrobociu (Dz. U. Nr 106, poz. 457, z późn. zm.).

Ustawa 10 grudnia 1993 r. o zaopatrzeniu emerytalnym żotnierzy i ich rodzin (Dz. U. z 2020 r., poz. 586).

Ustawa z dnia 14 grudnia 1994 r. o zatrudnieniu i przeciwdziałaniu bezrobociu (Dz. U. z 2001 r., Nr 6, poz. 56, z późn. zm.).

Ustawa z dnia 31 grudnia 1996 r. o stużbie wojskowej żotnierzy zawodowych (Dz. U.z 1997 r. $\mathrm{Nr} 10$, poz.55 z późn. zm.).

Konstytucja Rzeczypospolitej Polskiej z dnia 2 kwietnia 1997 r.

Ustawa z dnia 17 grudnia 1998 r. o zasadach użycia lub pobytu Sił Zbrojnych Rzeczypospolitej Polskiej poza granicami państwa (Dz. U. Nr 23, poz. 119, z późn. zm.).

Ustawa z dnia 18 grudnia 1998 r. o stużbie cywilnej (Dz. U. z 1999 Nr 49, poz. 483 z późn. zm.).

Ustawa z dnia 25 maja 2001 r. o przebudowie i modernizacji technicznej oraz finansowaniu Sit Zbrojnych RP w latach 2001-2006 (Dz. U. Nr 76, poz. 804 z późn. zm.). 
Ustawa z dnia 24 kwietnia 2009 r. o zmianie ustawy o stużbie wojskowej żolnierzy zawodowych (Dz. U. Nr 79, poz. 669).

Ustawa z dnia 10 czerwca 2010 r. o zmianie ustawy o stużbie wojskowej żolnierzy zawodowych (Dz. U. Nr 113, poz. 7450).

Rozporządzenie Ministra Obrony Narodowej z dnia 11 czerwca 1997 r. $w$ sprawie szczegółowych zasad i trybu przyuczenia do zawodu lub przekwalifikowania, doradztwa zawodowego, odbywania praktyk zawodowych oraz pośrednictwa pracy, realizowanych przez wyspecjalizowane organy wojskowe, a także szczegółowych zasad $i$ warunków korzystania z pomocy $w$ tym zakresie przez żolnierzy zwolnionych z zawodowej stużby wojskowej (Dz. U. z 1997 r. Nr 63, poz. 398 z późn. zm.).

Rozporządzenie Ministra Pracy i Polityki Socjalnej z dnia 14 października 1997 r. w sprawie szczegółowych zasad i trybu kierowania żolnierzy zwolnionych z zawodowej służby wojskowej do pracy na stanowiska pracy zwiąane z obronnościa kraju (Dz. U. z 1997 r. Nr 134, poz. 888 z późn. zm.).

Rozporządzenie Prezesa Rady Ministrów z dnia 26 września 1997 r. w sprawie określenia stanowisk pracy związanych z obronnościa kraju (Dz. U. Nr 124, poz. 787).

Rozporządzenie Ministra Obrony Narodowej z dnia 19 listopada 2014 r. w sprawie pomocy w zakresie doradztwa zawodowego, przekwalifikowania, pośrednictwa pracy i odbywania praktyk zawodowych (Dz. U. poz. 221).

Porozumienie z dnia 25 marca 1999 r. między Ministerstwem Obrony Narodowej a Urzędem Pracy o współpracy w zakresie tagodzenia skutków bezrobocia wśród byłych żotnierzy zawodowych.

Porozumienie z dnia 17 października 2002 r. między Ministrem Obrony Narodowej a Komendantem Głównym Straży Granicznej o współpracy w zakresie przyjmowania do stużby w Straży Granicznej bytych żotnierzy zawodowych.

Porozumienie z dnia 29 kwietnia 2003 r. między Ministrem Obrony Narodowej a Komendantem Głównym Policji o wspótpracy $w$ zakresie przyjmowania do stużby w Policji bytych żotnierzy zawodowych. 